\title{
Egg Storage Time Affects Incubation Yield and Hatch Window in Pekin Ducks (Anas Boschas)
}

\section{-Author(s)}

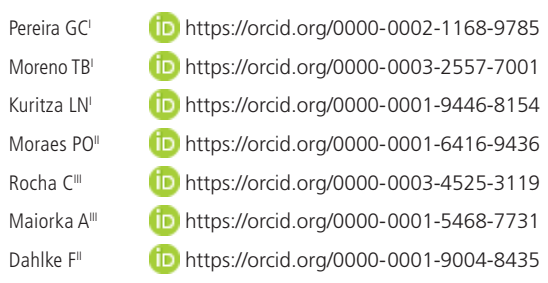

Graduate Program in Veterinary Science, Federal University of Paraná, Brazil.

Department of Animal Science, Federal University of Santa Catarina, Brazil.

II Department of Animal Science, Federal University of Paraná, Brazil.

\begin{abstract}
The objective of this study was to evaluate the effect of storage time on albumen quality, incubation yield, and hatch window in Pekin ducks (Anas boschas). A total of 1302 eggs were randomly distributed to seven treatments according to the storage time with durations ranging from 1 to 14 days. Each treatment consisted of 186 eggs with a twoday storage interval between treatments. The $\mathrm{pH}$ and Haugh unit (HU) of the albumen, egg weight loss during incubation (WL), hatchability $(\mathrm{HTCH})$, incubation duration (ID), hatch window, asymmetry (ASS), percentile kurtosis (PK), and embryonic mortality were analyzed. A linear effect was observed forthe WL, ID, and PK and a quadratic effect forpH, HU, and HTCH over time. No significant effect of storage time was observed on ASS. Post-pipping embryonic mortality was linearly affected by storage time. Prolonging the storage period above 10 days reduces albumen quality and hatchability, delays the hatch of Pekins, and results in a higher percentage of post-pipping mortality.
\end{abstract}

\section{INTRODUCTION}

The quality of fertile eggs in the poultry production chain is essential for the incubation and production of quality chicks (Tona, 2003). Pre-incubation storage time, environmental storage conditions, and breeder age are the most important factors in changing the internal characteristics of eggs (Tilki \& Inal, 2004; Abd El-Hack, 2019). Egg storage has become a common practice in commercial hatcheries, mainly due to the need to collect sufficient hatchable eggs that allows for uniformity and classification of eggs according to common characteristics, such as breeder age, batch, and sanitary state (Reijrink, 2009; Goliomytis, 2015).

Storage of chicken and turkey eggs for more than seven days alters the internal characteristics of the eggs, affects embryo development and survival, decreases hatchability, and reduces chick quality (Fasenko \& Robinson, 1998; Fasenko, 2001a; Fasenko, 2001b; Fasenko, 2007; Nasri, 2020). This is because, during storage, the eggs lose water and carbon dioxide to the environment, resulting in an increase in $\mathrm{pH}$ from 7.6 to 9.0 (Scott \& Silversides, 2000; Silversides \& Scott, 2001; Niemiec, 2001) and cell death can occur when the embryo is exposed to a $\mathrm{pH}$ of 9 for long periods (Reijrink, 2009). Furthermore, during the storage, oxidation of proteins and lipids of yolk and albumen occurs (Pappas, 2005) and increases in lipid peroxidation as the egg storage time is increased may compromise embryo viability (Cherian, 2007).

Besides, egg storage can prolong the incubation period, causing a delay in the hatching process (Brake, 1997; Decuypere, 2001; Elibol, 2002; Tona, 2003), resulting in hatching windows of up to 48 hours between late and early hatches (Careghi, 2005). The longer waiting 
Pereira GC, Moreno TB, Kuritza LN, Moraes PO, Rocha C, Maiorka A, Dahlke F
Egg Storage Time Affects Incubation Yield and Hatch Window in Pekin Ducks (Anas Boschas) time in the hatchery increases the post-hatch food deprivation period, resulting in weight loss due to dehydration, reabsorption of the yolk sac and protein catabolism, leading to limited initial growth (Careghi, 2005).

The effect of egg management (Gallus gallusdomesticus) prior to incubation and its effects in the postnatal phase have been extensively researched. However, the effect of storage time of Pekin (Anas boschas) eggs on embryonic development, incubation yield and hatch profile has not been adequately reported.

\section{MATERIALS AND METHODS}

The experiment was conducted after approval by the Ethics Committee on the Use of Animals of the Instituto Federal Catarinense, SC, Brazil, under protocol number 007/2013.

\section{Egg management and experimental design}

The experiment was carried in the city of Araquari, Santa Catarina, Brazil, in the coordinates26.395521 of latitude, -48.738669 of longitude and 9 meters of altitude. A total of 1302 freshly laid Pekin duck (Anas boschas) eggs, with an average weight of 85 $\pm 10 \mathrm{~g}$ aging 52- and 53-weeks, Cherry Valley SM2 lineage breeders were used in this study. All eggs came from the same farm and were collected/selected at two-day intervals ( $n=186$ per day of collection) and allocated to seven experimental groups. Eggs with a cracked, deformed, or very dirty shell, or with a poorly positioned air sac were excluded from the study at the time of egg selection. Selected eggs were numbered (identified) and weighed individually (scale accurate to 0.01g; model RB, BEL Engineering, Monza, Milan, Italy). After weighing, they were transported to a commercial hatchery and were subjected to the standard pre-incubation procedures: cleaning in warm water at $32{ }^{\circ} \mathrm{C}$; disinfection by immersion in chlorine solution (50 ppm) at $34{ }^{\circ} \mathrm{C}$ (15 seconds); ovoscopy to assess their integrity and finally, storage. Egg storage was carried out in an air-conditioned room, with a temperature of $17 \pm 1{ }^{\circ} \mathrm{C}$ and a relative humidity of $65 \%$. The eggs were equally distributed $(n=186)$ in seven groups, according to the storage length in the storage room (Table 1).

Table 1 - Experimental treatments according to the storage time of Pekin duck.

\begin{tabular}{l|c|c|c|c|c|c|c}
\hline Treatment & $2 \mathrm{~d}$ & $4 \mathrm{~d}$ & $6 \mathrm{~d}$ & $8 \mathrm{~d}$ & $10 \mathrm{~d}$ & $12 \mathrm{~d}$ & $14 \mathrm{~d}$ \\
\hline Storage (days) & 2 & 4 & 6 & 8 & 10 & 12 & 14 \\
\hline
\end{tabular}

\section{Assessment of internal egg quality}

After the respective storage periods, the eggs were weighed again and six were selected per treatment (85 $\pm 10 \mathrm{~g}$ ) for internal quality analysis. These eggs were opened on a flat surface and with the aid of a Haugh micrometer (Baxlo, Barcelona, Spain) the height of the dense albumen was measured to calculate the Haugh unit $(\mathrm{HU})$ using the Equation 1:

$$
H U=100 \times \log \left(h-1.7 \times W^{0.37}+7.57\right)
$$

where $\mathrm{HU}=$ Haugh Unit; $\mathrm{h}=$ albumen height $(\mathrm{mm})$; $\mathrm{W}=$ egg weight $(\mathrm{g})$.

After the measurement, the albumen $\mathrm{pH}$ was evaluated with the aid of a digital $\mathrm{pH}$ meter with an accuracy of 0.01 (PG1800, Gehaka, São Paulo, Brazil).

\section{Incubation parameters}

A total of 1,260 eggs were incubated, evenly distributed in a Petersime multi-stage incubator ${ }^{\circledR}$ (model VB336, Zulte, Belgium), at a temperature of $37.5^{\circ} \mathrm{C}$ and $65 \%$ humidity, with automatic turning every hour. On the eighth day of incubation, the eggs were submitted to ovoscopy for the removal of infertile eggs or those with early embryonic mortality. On the $24^{\text {th }}$ day of incubation (582 hours) the eggs were transferred to a Petersime ${ }^{\circledR}$ hatcher (model KK168, Zulte, Belgium), where they remained until hatching, which occurred on the $28^{\text {th }}$ day (on average at $672 \mathrm{~h}$ ), at a temperature of $37.5^{\circ} \mathrm{C}$ and relative humidity of $85 \%$ (wet bulb). Egg weight loss (\%) was calculated from the weight of the eggs at placement in the incubator and weight at transfer to the hatcher.

\section{Incubation yield and hatch window}

The duration of the incubation consisted of the time elapsed between the placement of the eggs in the incubator until the completion of the hatch, determined by the presence of unhatched eggs in the hatcher up to 18 hours (690 h) beyond the standard incubation period of $672 \mathrm{~h}$. Hatchability was determined by the relationship between the number of ducklings hatched, and the number of fertile eggs incubated (Equation 2):

HATCHABILITY $=\frac{100 \times\left(n^{\circ} \text { of ducklings hatched }\right)}{n^{\circ} \text { of fertile eggs incubated }}$

For embryo assessment, eggs identified during ovoscopy (on the $8^{\text {th }}$ day of incubation), and those that did not hatch at the end of the incubation period, were used. The eggs were opened and classified according to their contents into: infertile (INF); contaminated (CONT); with embryonic malformation (MF); early 
embryonic mortality (EEM) - from 1 to 9 days; intermediate (IEM) from 10 to 21 days; late embryonic mortality (LEM) - 22 to 28 days and post-pipping mortality (PPM) as described by Marques (1994).

From $645 \mathrm{~h}$, the hatcher was opened every $8 \mathrm{~h}$ to record the number of ducklings born. The birth curve was defined as the dispersion between hatching (\%) and incubation duration (h), and to trace its profile, birth asymmetry (ASS) and percentile coefficient of kurtosis (PK) were calculated according to Equations 3 and 4:

$$
\begin{aligned}
& A S S=\frac{3 \times(\text { mean }- \text { median })}{\text { standard deviation }} \\
& P K=\frac{(Q 3-Q 1)}{2 \times(P 90-P-10)}
\end{aligned}
$$

where: Q1 and Q3 = first and third quartile; P10 and $\mathrm{P} 90=$ the tenth and ninetieth percentiles.

\section{Statistical analysis}

The data were evaluated for normality of residuals and homogeneity of variance by the 'normal probability plot' and the 'std resids by fitted values' functions, respectively. When necessary, the data were transformed using the arc sine function and the 'Weight Variable' function was used to weight the values by their variance. The data were subjected to analysis of variance with derivation of the polynomials (regression analysis) using the 'Linear Regression' function of the statistical program, Statistix 8.0.

\section{RESULTS}

The increase in the storage period led to changes in the internal characteristics of the eggs and changes at hatching (Table 2), such as the increase in the $\mathrm{pH}$ of the albumen, a reduction of the $\mathrm{HU}$ and hatchability (quadratic regression $\mathrm{P}=0.004, \mathrm{P}=0.003$ and $\mathrm{P}=0.011$, respectively). There was linear weight loss in eggs $(P=0.002)$ and a longer incubation duration $(P=0.010)$, as the egg storage time increased.

In all groups, hatching displayed a positive asymmetric distribution (ASS $>0$ ), indicating a nonuniformity in the Pekin hatch, with a predominance or higher frequency of hatching at times above the average period, regardless of the treatment evaluated. The storage time did not affect the symmetry of the hatch curve $(p>0.05)$. Furthermore, hatches presented a leptokurtic curve $(C<263)$ in all treatments evaluated, with a tendency to attenuate this behaviour as the storage time of the eggs increased (linear $p<0.001$ ).
Table 2 - Average values for albumen $\mathrm{pH}$, Haugh unit (HU), egg weight loss during incubation (WL, \%), hatchability ( $\mathrm{HTCH}, \%)$, asymmetry (ASS), and percentile coefficient of kurtosis (PK, \%) in the distribution of the hatch of Pekin eggs submitted to different storage periods.

\begin{tabular}{lcccccc}
\hline Storage time (days) & $\mathrm{pH}^{1}$ & $\mathrm{HU}^{2}$ & $\mathrm{WL}^{3}$ & $\mathrm{HTCH}^{4}$ & $\mathrm{ASS}$ & $\mathrm{PK}^{5}$ \\
\hline 2 & 9.45 & 92.79 & 5.46 & 92.22 & 1.791 & 0.059 \\
4 & 9.68 & 88.18 & 6.33 & 90.32 & 1.785 & 0.055 \\
6 & 9.60 & 86.26 & 6.33 & 89.27 & 1.463 & 0.050 \\
8 & 9.79 & 85.85 & 7.49 & 89.39 & 1.887 & 0.050 \\
10 & 9.85 & 85.82 & 8.34 & 85.72 & 1.518 & 0.052 \\
12 & 9.86 & 86.71 & 7.90 & 83.14 & 1.095 & 0.041 \\
14 & 9.87 & 85.67 & 8.32 & 79.62 & 1.158 & 0.047 \\
\hline & \multicolumn{5}{c}{ Probability } \\
\hline Linear & 0.000 & 0.000 & 0.002 & 0.047 & 0.767 & 0.0001 \\
Quadratic & 0.004 & 0.003 & 0.23 & 0.011 & 0.251 & 0.656 \\
\hline CV (\%) & 12.52 & 4.13 & 17.5 & 2.67 & 30.17 & 18.76 \\
\hline
\end{tabular}

$\mathrm{CV}=$ coefficient of variation

${ }^{1} 0.0026 x^{2}+0.08527+9.2639 ; R^{2}=0.81 ;$

${ }^{2} 0.15086 x^{2}-2.53714+96.196 ; R^{2}=0.70 ;$

${ }^{3} 0.241086 x+5.219 ; R^{2}=0.78 ;$

${ }^{4}-0.0694 x^{2}+0.0468+91.763 ; R^{2}=0.76 ;$

${ }^{5} 0.00157 x+0.06097 ; R^{2}=0.49$.

The incubation duration (hours) increased in response to storage time (Figure 1). The first hatches occurred on average after $656 \mathrm{~h}$ of incubation, increasing, on average, up to $680 \mathrm{~h}$, resulting in a difference of 24 hours in hatching between the Pekins from eggs stored for two and 14 days.

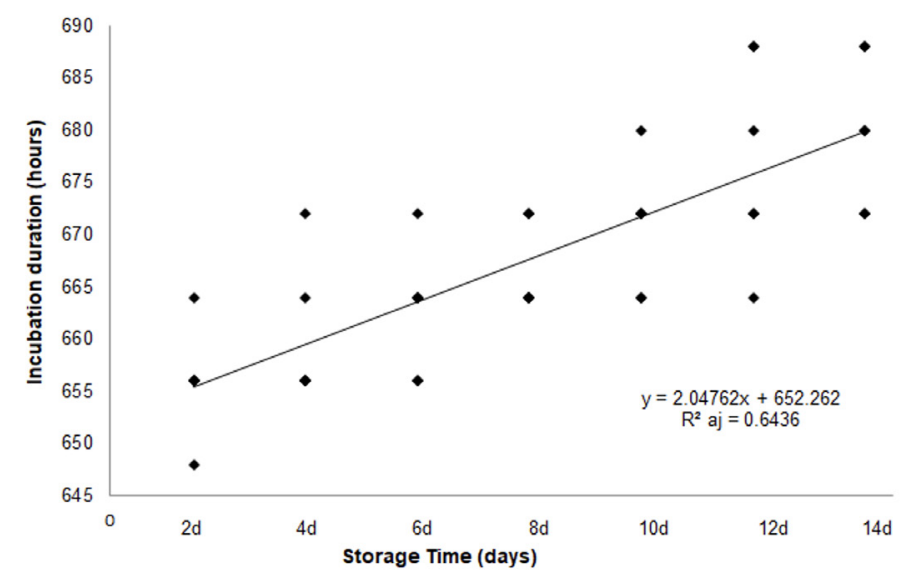

Figure 1 - Incubation duration (hours) of Pekin eggs subjected to increasing storage times.

Figure 2 shows the hatching distributions (\%), according to the treatments evaluated. In addition to leptokurtic kurtosis, there is a displacement of the hatch curve, from ten days of egg storage, extending the hatch up to 688 hours of incubation.

The embryo evaluation (Table 3 ) indicated that there was no effect of the storage period on the rates of embryonic malformation in the early, intermediate or late embryonic stages ( $p>0.05)$. However, there was an 


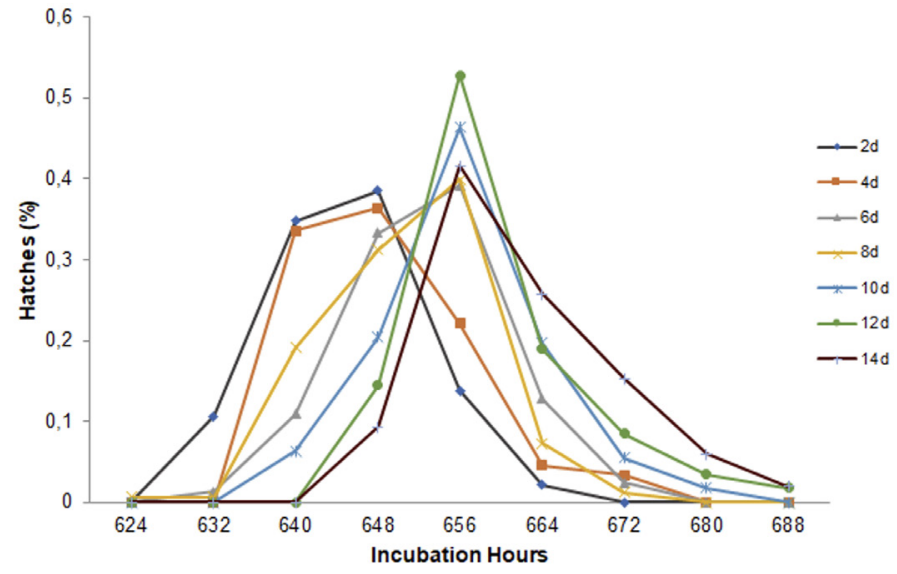

Figure 2 - Percentage distribution of Pekin egg hatches subjected to increasing storage times.

increase (quadratic, $p=0.013$ ) in mortality during the post-pipping phase with increased pre-incubation egg storage period (Figure 3).

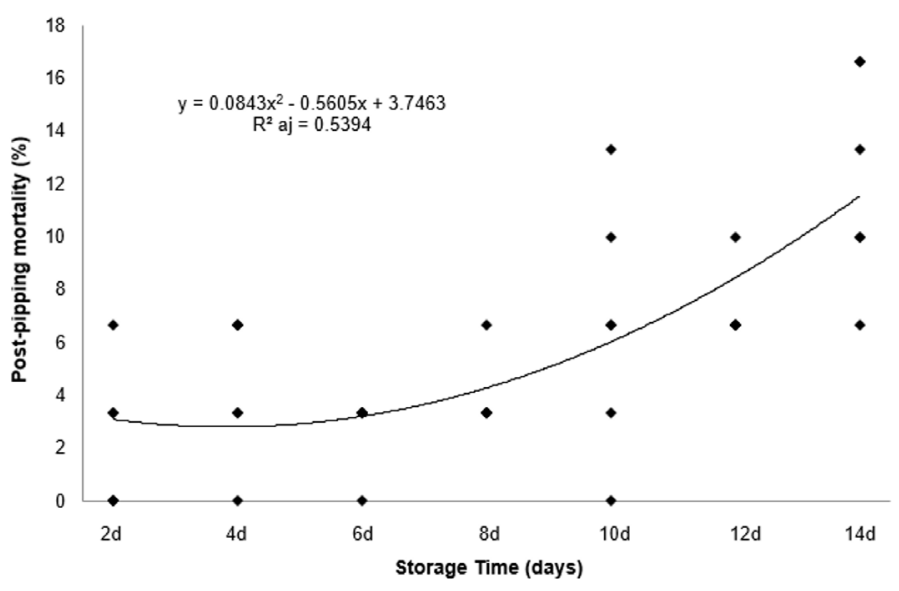

Figure 3 - Post-pipping mortality of Pekin embryos with increasing storage times.

Table 3 - Profile of non-hatched Pekin eggs (\%), attributed to contamination (CONT), embryonic malformation (MF), with identification of early embryonic mortality (EEM), intermediate (IEM) and late embryonic mortality (LEM) when eggs were submitted to different storage periods.

\begin{tabular}{lccccc}
\hline Storage time (days) & CONT & MF & EEM & IEM & LEM \\
\hline 2 & 1.11 & 0.00 & 4.44 & 0.00 & 0.00 \\
4 & 2.22 & 0.00 & 2.78 & 0.56 & 0.00 \\
6 & 1.67 & 0.56 & 5.00 & 0.56 & 0.56 \\
8 & 1.67 & 1.11 & 2.78 & 1.11 & 0.00 \\
10 & 2.22 & 0.56 & 2.22 & 0.00 & 2.22 \\
12 & 2.78 & 1.67 & 2.78 & 0.56 & 1.67 \\
14 & 2.22 & 2.22 & 0.56 & 0.00 & 2.78 \\
\hline Mean & 1.98 & 0.87 & 2.94 & 0.40 & 1.03 \\
\hline \multicolumn{5}{c}{ Probability } \\
\hline Linear & 0.630 & 0.910 & 0.829 & 0.167 & 0.972 \\
Quadratic & 0.822 & 0.561 & 0.389 & 0.142 & 0.369 \\
\hline CV (\%) & 1.25 & 1.05 & 1.65 & 0.69 & 1.19 \\
\hline
\end{tabular}

$\mathrm{CV}=$ coefficient of variation

\section{DISCUSSION}

As expected, there was a gradual change in the internal quality of the eggs, observed by the increase in $\mathrm{pH}$ of the albumen and the reduction of $\mathrm{HU}$ in response to the increase in storage time, concurring with the results found in chicken eggs (Tona, 2003; Jones \& Musgrove, 2005). The results found in this study are also in agreement with data from Onbaşılar (2007), who observed a reduction of 82 to $66.6 \mathrm{HU}$ in Pekin eggs stored from 0 to 11 days. The $\mathrm{HU}$ values observed in this study, ranging from 92.79 to 85.67 $\mathrm{HU}$ for eggs stored for 2 to 14 days, respectively, are higher than previously published values.

In chickens, the $\mathrm{pH}$ of the albumen at the time of oviposition is around 7.6, rising to 9 during storage (Scott \&Silversides, 2000; Silversides \&Scott, 2001; Niemiec, 2001). Reijrink (2009), however, has indicated 8.2 to 8.8 as the best albumen pH for embryonic development in Gallus gallus, because embryonic cells are sensitive to a high albumen $\mathrm{pH}$ (above $\mathrm{pH}$ 9), leading to disproportionate development or even embryonic death (Brake, 1997; Reijrink, 2009). A gradual increase in the $\mathrm{pH}$ of the albumen was observed with storage, but even after oviposition, the values were higher than those commonly found in chicken eggs, indicating a different $\mathrm{pH}$ for this species. In anatids, the initial albumen $\mathrm{pH}$ is normally between 8.3 and 8.6 (Alleoni \& Antunes, 2001; Onbaşilar, 2011; Quan \& Benjakul, 2018; Nasri ,2020).

According to Quan \& Benjakul (2018) changes in $\mathrm{pH}$ and liquefaction of albumen, observed when duck eggs are stored, occur by conversion of $\mathrm{H}_{2} \mathrm{CO}_{3}$ into water and $\mathrm{CO}_{2}$. These chemical modifications cause part of the formed water to evaporate through the shell pores, releasing $\mathrm{CO}_{2}$ and altering the internal structure of the egg (De Oliveira \& Oliveira, 2013; Onbaşılar et. al., 2007). Long storage periods can lead to excessive degradation of the albumen, leading to the movement of the blastoderm to the shell, dehydration, and embryonic mortality (Brake, 1997). The reduction of ambient temperature seems to be an effective tool in mitigating these deleterious effects, as it prevents the diffusion of gases through the shell (carbon dioxide) and allows the retention of internal moisture of the egg, which reduces mortality (Reijrink, 2009).

Weight loss during incubation was higher in eggs that were stored for longer periods, similar to the results found in studies with chicken eggs (Pedroso ,2006; Barbosa , 2008; Garcia , 2010). For chickens and Pekins, the recommended rate of egg weight loss 
is between 11 and 14\% (Rosa \& Avila, 2000). Silva (2008) observed that weight loss can be above the recommended level when the eggs are stored for 14 days. In Pekin ducks, Onbaşılar (2007) verified that egg weight loss occurs during the storage period, with values ranging from 0.38 to $1.58 \%$ for periods of 3 and 11 days, respectively. However, there was no difference in weight loss during incubation as a function of storage period, which ranged from 11 to $13 \%$.

The predicted hatchability in Pekin eggs is 85 to $87 \%$ (Klein-Hessling, 2007). In this study, hatchability was within the expected levels when the eggs were stored for a maximum of ten days. However, from this period on, there is a reduction of up to $6 \%$ in hatchability, resulting in indices below the recommended hatchability. That is, for every day of storage, from the 10 th day on, there is a reduction of about $0.99 \%$ in hatchability. Onbaşılar (2007) also observed a reduction from 96.2 to $79.1 \%$ in the hatchability of Pekin eggs stored from 3 to 11 days. In chickens, this reduction is observed earlier, from the $4^{\text {th }}$ day of egg storage (Reis, 1997; Lapão, 1999), with a reduction of $1.38 \%$ per day, up to the $8^{\text {th }}$ day of storage (Schmidt, 2009). For turkey eggs, Fasenko (2001a) reported that eggs stored for 4 or 14 days presented a hatchability rate of $70.9 \%$ and $64.4 \%$, respectively.

The reduction in hatchability of eggs stored for long periods results from necrosis and morphological changes in the blastoderm (Asmundson \& Macilraith, 1948; Arora \& Kosin, 1966; Lapão, 1999; Decuypere, 2001). However, short periods (3 to 7 days) seem to benefit incubation due to the reduction in the viscosity of the albumen, which allows greater diffusion of oxygen and nutrients such as glucose and ions to the embryo (Meuer \& Baumann, 1988; Burley \& Vadehra, 1989; Goodrum , 1989; Brake, 1997; Nasri , 2020).

Incubation duration increased linearly as egg storage time increased. Several studies have reported the same behaviour with chicken eggs (Reis, 1997; Tona, 2003; Pedroso, 2006). According to Fasenko \& Robinson (1998), cell activity during the first 12 $\mathrm{h}$ of incubation is lower in eggs stored for 14 days, compared to those stored for four days. The same authors observed that the development of the embryo in eggs stored for long periods begins on average $6 \mathrm{~h}$ later than the development of embryos from eggs with short storage periods, which can lead to differences in hatching times.

In the current study, the extension of one day in storage time leads to an increase of $2 \mathrm{~h}$ in incubation time. When evaluating the effects of egg storage for 10 or 20 days on oxygen consumption, heartbeat and $\mathrm{O}_{2}$ pulse in chicken embryos, Haque (1996) observed that prolonged storage time (20 days) negatively affects the physiological functions of embryos and leads to a delay in embryo development. Oxygen consumption is significantly lower over the final incubation period in eggs stored for 20 days, resulting in a negative effect on embryonic viability. The $\mathrm{O}_{2}$ pulse in egg embryos stored for 20 days is also lower than that of embryos from eggs stored for 10 days, which is an important factor in determining embryonic death. According to the same authors, these physiological changes resulting from prolonged storage time can cause a delay of more than one day in hatching.

According to Bloom \& Muscarella (1998), the percentage of apoptotic cells at the time of oviposition is approximately $3.1 \%$, and after 14 days of storage, this value can reach $13.9 \%$, resulting in less viable cells. Hamidu (2011) evaluated cell mortality and embryonic quality in chicken eggs stored for 4 or 14 days and also found that the percentage of viable embryonic cells was significantly higher in eggs stored for 4 days $(81.17 \%)$ compared to 14 days (68.18\%); moreover, the percentage of apoptotic cells was significantly higher in eggs stored for 14 days (17.88\%) compared with eggs stored for 4 days (4.32\%). The authors report that the reduction in the number of blastoderm cells may limit the number of cells available for $\mathrm{O}_{2}$ absorption, which may cause a reduction in the availability of this nutrient for metabolic activities related to the use of carbohydrates, fats, and proteins to generate energy and nutrients for embryonic growth.

Changes in the number and quality of viable cells in eggs stored for long periods may cause a significant delay in the onset of embryonic development after incubation compared to development in eggs stored for shorter periods (Nasri, 2020). Thus, the increase in incubation duration verified in this study may be due to the delay in the beginning of embryogenesis after the beginning of the incubation process or the reduction in the rate of embryonic development throughout incubation, which may be directly associated with a longer storage time.

Another important factor to be evaluated is the hatch window, represented by a distribution curve of hatching over time. The distribution of hatching presented a positive asymmetric distribution, regardless of the egg storage period $(p<0.05)$. Although the hatch distribution curves presented a leptokurtic kurtosis (with higher peaks than in a normal distribution 
curve), as the egg storage time increased, there was a tendency $(p<0.001)$ for a greater distribution of hatches over time (platykurtic kurtosis: flattening of the curve). At the same time, there was a more marked displacement, or delay, of the hatch curves when the eggs were stored for longer than 10 days.

A hatch curve with a narrower and symmetrical base is considered ideal, indicating a higher concentration of hatching within the same time interval, reducing the negative effects of a longer stay in the hatchery (Calil, 2007). A wider hatch window and a longer stay in the hatcher can have negative effects on hydration, thermal comfort, umbilical healing, survival, use of residual yolk, and maturity of the immune and gastrointestinal system of the chick (Boerjan, 2006; Hodgetts, 2006; Padrón, 2009). It also affects hatchery planning and has long-lasting effects on birds, which is reflected in poor performance in the field.

The post-pipping mortality increased as the storage time was prolonged, especially from the $8^{\text {th }}$ day. In contrast, Onbaşılar (2007) found higher mortality rates in the early stages of embryonic development in Pekins. When evaluating the storage period of 2 or 12 days, Okur (2018) observed that early embryonic mortality in chicken eggs $(7.88 \%$ and $3.21 \%$, respectively) and late mortality + post-pipping mortality + unhatched eggs $(6.26 \%$ and $2.14 \%$, respectively), were higher after 12 days of storage compared to eggs stored for two days.

Longer duration of incubation and the increase in mortality may be related to changes in embryonic metabolism over prolonged periods of egg storage. Embryonic $\mathrm{CO}_{2}$ production is slower in eggs stored for 15 days compared to eggs stored for four days, demonstrating that embryonic metabolism slows down with longer storage periods (Fasenko, 2002). In addition, cardiac muscles depend on hepatic gluconeogenesis to obtain energy during anaerobic metabolism, and egg embryos stored for 14 days have a lower amount of hepatic glycogen compared to egg embryos stored for one day (Christensen, 2002). A hypothesis that explains the higher post-pipping embryonic mortality is that the Pekins of eggs stored for long periods do not produce enough energy through gluconeogenesis to attend the energy demand of the hatching process.

\section{CONCLUSIONS}

In conclusion, prolonging the storage period reduces egg quality, reduces hatchability, delays the hatching of Pekins, and results in a higher post-pipping mortality percentage. Thus, it is recommended that the egg storage period of Pekins intended for incubation be less than 10 days.

\section{REFERENCES}

Abd El-Hack ME, Hurtado CB, Toro MDM, Alagawany EM, Abdelfattah EM, Elnesr SS. Fertility and hatchability in duck eggs. World's Poultry Science Journal 2019;75:559-608

Alleoni ACC, Antunes AJ. Unidade Haugh como medida da qualidade de ovos de galinha armazenados sob refrigeração. Scientia Agrícola 2001;58:681-685

Arora LL, Kosin IL. Developmental response of early turkey and chicken embryos to preincubation holding of eggs:Inter-and intra-species differences. Poultry Science 1966;45:958-970.

Asmundson VS, Macilraith JJ. Preincubation tests with turkey eggs. Poultry Science 1948;27:394-401.

Barbosa NAA, Sakomura NK, Mendonça O. Qualidade de ovos comerciais provenientes de poedeiras comerciais armazenados sob diferentes tempos e condições de ambientes. ARS Veterinária 2008;24:127-133.

Bloom SE, Muscarella DE. Stress responses in the avian early embryo: regulation by pro- and anti-apoptotic cell death genes. Poultry Avian Biology 1998;9:43-55.

Boerjan M. Economics of a short hatch window. The Poultry Site; 2006 Available from: http://www.thepoultrysite.com/articles/594/theeconomics-of-a-short-hatch-window.

Brake J, Walsh TJ, Benton CE, Petitte JN, Meijerhof R, Peñalva G. Egg handling and storage. Poultry Science 1997;76:144-151.

Burley RW, Vadehra DV. The avian egg: chemistry and biology. New York: John Wiley and Sons; 1989.

Calil, TAC. Control of the birth window. = O controle da janela de nascimento. 2007 [cited 2020 Sept 9]. Available from: http://www. avisite.com.br/cet/img/20100806_janela.pdf.

Careghi C, Tona K, Onagbesan O, Buyse J, Decuypere E, Bruggeman V. The effects of the spread of hatch and interaction with delayed feed access after hatch on broiler performance until seven days of age. Poultry Science 2005;84:1314-1320.

Cherian G, Traber MG, Goeger MP, Leonard SW. Conjugated linoleic acid and fish oil in laying hen diets:effects on egg fatty acids, thiobarbituric acid reactive substances, and tocopherols during storage. Poultry Science 2007;86:953-958.

Christensen VL, Wineland MJ, Fasenko GM, Donaldson WE. Egg storage effects on plasma glucose and supply and demand tissue glycogen concentrations of broiler embryos. Poultry Science 2002;80:17291735

Decuypere E, Tona, K, Bruggeman, V,Bamelis, F. The day-old chick: a crucial hinge between breeders and broilers. World's Poultry Science Journal 2011;57:127-139.

De Oliveira BL, Oliveira DD. Qualidade e tecnologia de ovos. Lavras: Editora UFLA, 2013.

Elibol O, Peak SD, Brake J. Effect of flock age, length of egg storage, and frequency of turning during storage on hatchability of broiler hatching eggs. Poultry Science 2002;81:945-950. 
Fasenko GM, Robinson FR. Identification of the incubation period when broiler breeder embryonic development is delayed due to egg storage for 14 versus 4 days. Poultry Science 1998;77(Suppl 1):77.

Fasenko GM, Christensen VL, Wineland MJ, Petitte JN. Examining the effects of prestorage incubation of turkey breeder eggs on embryonic development and hatchability of eggs stored for four or fourteen day. Poultry Science 2011a;80(2):132-138.

Fasenko GM, Robinson FE, Whelan Al, Kremeniuk KM, Walker JA. Prestorage incubation of long-term stored broiler breeder eggs: 1. effects on hatchability. Poultry Science 20011b;80:1406-1411.

Fasenko GM, Robinson JFE, Segura JC, Feddes JR, Ouellette CA. Long term hatching egg storage alters the metabolism of broiler embryos. Poultry Science 2002;80(Suppl.):62.

Fasenko GM. Egg storage and the embryo. Poultry Science 2007:86:10201024.

Garcia ERDM, Orlandi CCO, De Oliveira CAL, Da Cruz FK, Dos Santos TMB, Otutumi LK. Qualidade de ovos de poedeiras semipesadas armazenados em diferentes temperaturas e períodos de estocagem. Revista Brasileira de Saúde e Produção Animal 2010;11:505-518.

Goliomytis M, Tsipouzian AT, Hager-Theodorides L. Effects of egg storage on hatchability, chick quality, performance and immunocompetence parameters of broiler chickens. Poultry Science 2015;94:2257-2265.

Goodrum JW, Britton WM, Davis JB. Effect of storage conditions on albumen $\mathrm{pH}$ and subsequent hard-cooked egg peelability and albumen shear strength. Poultry Science1989; 68, 1226-1231.

Hamidu JA, Fasenko GM, Guan L, Barreda DR, Feddes JJR. Influence of parent flock age on embryonic metabolism in modern turkey strains. Poultry science 2011;90:426-434.

Haque MA, Pearson JT, Hou PCL, Tazawa H. Effects of pre-incubation egg storage on embryonic functions and growth. Respiration Physiology 1996;103:89-98.

Hodgetts B. Successfully closing the hatch window. International Hatchery Practice 2006;20:23 [cited 2020 Sept 09]. Available from: http://www. positiveaction.info/pdfs/articles/hp20.5p23.pdf

Jones DR, Musgrove MT. Effects of extended storage on egg quality factors. Poultry Science 2005;84:1774-1777

Klein-Hessling, H. Peking duck breeders require special management. World Poultry 2007;23:14-18.

Lapão C, Gama LT, Soares MC. Effects of broiler breeder age and length of egg storage on albumen characteristics and hatchability. Poultry Science 1999;78:640-645.

Meuer HJ, Baumann R. Oxygen pressure in intra- and extraembryonic blood vessels of early chick embryo. Respiration Physiology 1988;71:331-341.

Nasri $H$, van den Brand H, Najjar T, Bouzouaia M. Egg storage and breeder age impact on egg quality and embryo development. Journal of Animal Physiology and Animal Nutrition2020; 104:257-268.

Niemiec J, Stepínska M, Swierczewska E, Riedel J, Boruta A. The effect of storage on egg quality and fatty acid content in PUFA-enriched eggs. Journal of Animal and Feed Sciences 2001;10:267-272.
Okur N, Eleroğlu H, Türkoğlu M. Impacts of breeder age, storage time and setter ventilation program on incubation and post-hatch performance of broilers. Brazilian Journal of Poultry Science 2018;20:27-36.

Onbaşilar EE, Erdem E, Poyraz Ö, Yalçin S. Effects of hen production cycle and egg weight on egg quality and composition, hatchability, duckling quality, and first-week body weight in Pekin ducks. Poultry Science 2011:90:2642-2647.

Onbașilar EE, Poyraz Ö, Erdem E. Effects of egg storage period on hatching egg quality, hatchability, chick quality and relative growth in Pekin ducks. Archiv Fur Geflugelkunde 2007;71:187-191.

Padrón M, Fancher B, Gaytan E, Malagón G. Influencia del tiempo de nacimiento sobre el desempeño del pollito durante laprimera semana. Engomix; 2009 [cited 2020 Sept 9]. Available from: https://www. engormix.com/avicultura/articulos/influencia-tiempo-nacimientosobre-t26222.htm

Pappas AC, Acamovic T, Sparks NHC, Surai PF, McDevitt RM. Effects of supplementing broiler breeder diets with organic selenium and polyunsaturated fatty acids on egg quality during storage. Poultry Science 2005;84:865-874.

Pedroso AA, Café MB, Leandro NSM, Stringhini JH, Chaves LS Desenvolvimento embrionário e eclodibilidade de ovos de codornas armazenados por diferentes períodos e incubados em umidades e temperaturas distintas. Revista Brasileira de Zootecnia 2006:35:23442349.

Reijrink I. Good egg storage to obtain more chicks. World Poultry 2009;25:02. [cited 2020 Sept 9]. Available from: https://www. poultryworld.net/Layers/Eggs/2009/7/Good-egg-storage-to-obtainmore-chicks-WP006934W/

Reis LH, Gama, LT,Soares, MC. Effects of short storage conditions and broiler breeder age on hatchability, hatching time, and chick weights. Poultry Science 1997;76:1459-1466.

Rosa PS, Ávila VS. Variáveis relacionadas ao rendimento da incubação de ovos em matrizes de frangos de corte [comunicado técnico 246]. Concórdia: Embrapa Suínos e Aves; 2000.

Schmidt GS, Figueiredo EAP, Saatkamp MG, Bomm ER. Effect of storage period and egg weight on embryo development and incubation results. Brazilian Journal of Poultry Science 2009;11:1-5.

Scott TA, Silversides FG. The effect of storage and strain of hen on egg quality. Poultry Science 2000;79:1725-1729.

Silversides FG, Scott TA. Effect of storage and layer age on quality of eggs from two lines of hens. Poultry Science 2001;80:1240-1245.

Silva FHA, Faria DE, Torres KAA, Faria Filho DE, Coelho AAD, Savino VJM. Influence of egg pre-storage heating period and storage length on incubation results. Brazilian Journal of Poultry Science 2008;10:17-22.

Silversides FG, Scott TA. Effect of storage and layer age on quality of eggs from two lines of hens. Poultry Science 2001;80:1240-1245.

Tilki M, Inal S. Quality traits of goose eggs:1. Effects of goose age and storage time of eggs. Archiv fur Geflugelkunde 2004;68:182-186.

Tona K. Effects of short storage conditions and broiler breeder age on hatchability, hatching time, and chick weights. Poultry Science 2003:82:736-741. 
